\title{
On climate change and vision in crises
}

\author{
Tam-Tri Le \\ Centre for Interdisciplinary Social Research \\ Phenikaa University, Hanoi, Vietnam \\ Written in Ho Chi Minh City on 10 August 2021 \\ OSF Preprints, DOI: 10.31219/osf.io/8vm6b
}

In recent weeks, many Southern Europe regions have been devastated by wildfires, and climate change - not unexpectedly - is considered a major factor that increases the risk of such environmental disasters [1]. the Intergovernmental Panel on Climate Change (IPCC) has just reported the global climate status as the temperature change is coming close to the $1.5^{\circ} \mathrm{C}$ threshold, which is deemed a "Code Red for humanity" by the United Nations' Secretary-General [2].

The lifespan of each human and even the whole humanity is too short compared to the Earth's biosphere, but it is not necessary that our vision should be as short. Some of us are very aware of the ways of wisdom, which ensure not only our long-term survival but also our virtues as an intelligent species. Unfortunately, many people and institutions either cannot or choose not to put their mind and heart onto such paths, even when suffering is apparent.

Looking at the similarities between responses to COVID-19 and climate change, researchers found three well-used justifications for collective inaction: denialism, individualism, and technooptimism [3]. It is the same old story of prioritizing profit over human well-being - and worse - in the face of global crises, where deaths and heartbreak are everywhere every day. What more would it take for us to realize the (seemingly natural) principle of sustainability: to humans, while natural properties can be seen as financially valuable, our monetary value cannot account for the goodness of nature [4] - and thus, money can be used to improve environmental qualities, but in the opposite direction, nature cannot be sacrificed to make money.

Proper environmental policies are highly complex, having various interconnections with other socioeconomic aspects, and have always been a difficult problem for both developed and developing countries [5,6]. Under multiple global crises as of now, we should be aware that in the present age, collective social behaviors need to be examined not only within national boundaries, but rather on the basis of a deeply globalized world [7].

While many are trying to become oblivious of morality, it is clear to others that intention determines the direction where the blade of human ability is pointed. Belief can drive the mind to either extremes of demons or saints, leading to either destruction and terror or collaboration and peace on a global level [8]. Again, toward climate change, good spiritual values from both religious and non-religious perspectives can open our eyes and hearts to the natural harmony of this planet which has always been nurturing our very human existence [9]. 


\section{References}

1. Braun, S. (2021). Europe is burning: Four explanations. Deutsche Welle. https://www.dw.com/en/europe-is-burning-four-explanations/a-58771341

2. United Nations. (2021). Secretary-General Calls Latest IPCC Climate Report 'Code Red for Humanity', Stressing 'Irrefutable' Evidence of Human Influence. https://www.un.org/press/en/2021/sgsm20847.doc.htm

3. Stuart, D., Petersen, B., \& Gunderson, R. (2021). Shared pretenses for collective inaction: The economic growth imperative, COVID-19, and climate change.

Globalizations, 1-18. https://doi.org/10.1080/14747731.2021.1943897

4. Vuong, Q.-H. (2021). The semiconducting principle of monetary and environmental values exchange. Economics and Business Letters, 10(3), 284-290.

https://reunido.uniovi.es/index.php/EBL/article/view/15872

5. Vuong, Q., et al. (2021). Identifying the moral-practical gaps in corporate social responsibility missions of Vietnamese firms: An event-based analysis of sustainability feasibility. Corporate Social Responsibility and Environmental Management, 28(1), 3041. https://doi.org/10.1002/csr.2029

6. Vuong, Q.-H., Ho, T., Nguyen, H. K., \& Nguyen, H. (2019). The trilemma of sustainable industrial growth: Evidence from a piloting OECD's Green city. Palgrave Communications, 5, 156. https://doi.org/10.1057/s41599-019-0369-8

7. Kashima, Y. (2021). COVID-19, societal threats, and social psychology's self-imposed constraint. Asian Journal of Social Psychology, 24(1), 30-33. https://doi.org/10.1111/ajsp.12464

8. Vuong, Q.-H., Nguyen, M.-H., \& Le, T.-T. (2021). A Mindsponge-Based Investigation into the Psycho-Religious Mechanism Behind Suicide Attacks. Sciendo.

https://doi.org/10.2478/9788366675599

9. Kieran, P. (2021). The world's religious traditions and global climate disruption. In Teaching Climate Change in Primary Schools. Routledge. 